九州大学学術情報リポジトリ

Kyushu University Institutional Repository

Protein Profiles of Larval Haemolymph of Bombyx mori in Artificially Induced Trimolting Larvae using a 1,5-disubstituted Imidazole

Kawaguchi, Yutaka

Laboratory of Sericultural Science, Faculty of Agriculture, Kyushu University

Akagi, Shunsuke

Laboratory of Sericultural Science, Faculty of Agriculture, Kyushu University

Banno, Yutaka

Laboratory of Sericultural Science, Faculty of Agriculture, Kyushu University

Koga, Katsumi

Laboratory of Sericultural Science, Faculty of Agriculture, Kyushu University

他

https://doi.org/10.5109/24207

出版情報 : 九州大学大学院農学研究院紀要. 42 (1/2)，pp. 203-209，1997-12. 九州大学農学部 バージョン：

権利関係 : 


\title{
Protein Profiles of Larval Haemolymph of Bombyx mori in Artificially Induced Trimolting larvae using a 1,5-disubstituted Imidazole
}

\author{
Yutaka Kawaguchi' ${ }^{1 * *}$, Shunsuke Akagi ${ }^{1)}$, Yutaka Banno ${ }^{1)}$, \\ Katsumi Koga ${ }^{1)}$, Eiichi Kuwano ${ }^{2)}$ and Hiroshi Doira ${ }^{3)}$ \\ ${ }^{1}$ Laboratory of Sericultural Science, ${ }^{2}$ Laboratory of Pesticide Chemistry and \\ 3)Institute of Genetic Resources, Faculty of Agriculture, \\ Kyushu University, Fukuoka 812-81, Japan \\ (Received August 11, 1997 and accepted August 25, 1997)
}

\begin{abstract}
Trimolter larvae (undergoing three larval molts) of Bombyx mori were induced artificially by administrating 1-benzyl-5-[(E)-2,6)-dimethyl-1,5-heptadienyl]-imidazole (an insect growth regulator called KK-42) shortly after the third molt, and analyzed by polyacrylamide gel electrophoresis for the banding patterns of haemolymph proteins. The features were similar to those previously reported for allatectomy-induced trimolters, which mimicked the trait of the recessive trimolting mutant $r t$ rather than that of the dominant trimolting mutant $M^{*}$.
\end{abstract}

\section{INTRODUCTION}

The haemolymph of Bombyx mori have many kinds of proteins, whose concentration and constitution fluctuate remarkably during the periodic feeding and molting stages of larval life (Kobara, 1967; Doira, 1968). Until the penultimate instar, the concentration of total haemolymph proteins increases during each feeding period and decreases at each molt (Kawaguchi et al., 1983). At the young (the first to the third) instars the proteins named PYL-A and PYL-B (Fujiwara and Yamashita, 1990; Banno et al., 1993) predominate in the haemolymph. On the other hand, the final (normally the fifth) larval instar is characterized by the rapid increase in concentration of overall haemolymph proteins, including the major components called storage protein 1 (SP-1) or female specific protein (FL), storage protein 2 (SP-2) and $30 \mathrm{kDa}$ proteins (Kawaguchi and Doira, 1973; Tojo et al., 1980; Kawaguchi et al., 1993, 1994).

As to the moltinism (molting character in particular its number), the tetramolter which repeats four larval molts (and thus five larval instars) is considered as the normal (standard) type in B. mori. The number of larval molts is genetically fixed; there are dimolters, trimolters and pentamolters as mutants of moltinism. Genetic analyses of these mutants have shown that the moltinism in $B$. mori is controlled by at least three genes called mod, $r t$ and $M$ (Doira et al., 1992). The molting number can also be reduced artificially by the extirpation of corpora allata from larvae at the third or fourth instar to make precocious pupae skipping the fourth ecdysis (Kim, 1939; Fukuda, 1940). Also anti-hormone compounds have the ability to alter the number of larval molting (Asano et al., 1982; Kuwano, 1987).

In the present study, we treated normal B. mori larvae with 1-benzyl-5-[(E)-2,6)-

*Corresponding author. 
dimethyl-1,5-heptadienyl]-imidazole (KK-42), which is an imidazole derivative having the anti-ecdysteroid activity (Kadono-Okuda et al., 1987; Kuwano et al., 1992; Suzuki and Kuwno, 1994), and resulting trimolter larvae were analyzed for haemolymph proteins. Profiles were compared with those which we have reported previously for allatectomyinduced trimolters and for genetic trimolters $r t$ and $M^{3}$ (Kawaguchi et al., 1993, 1994).

\section{MATERIALS AND METHODS}

\section{Strain of silkworm used}

The t011 strain stocked in the Institute of Genetic Resources, Faculty of Agriculture, Kyushu University, was used. This is a normal tetramolter $\left(+^{M}\right)$, and includes the sexlimited dominant zebra gene (Ze) translocated to the $\mathrm{W}$ chromosome $(\mathrm{T}(\mathrm{W} ; 3) Z e\}$ (Doira $e t$ $a l ., 1992)$; thus larvae can be discriminated between female $(Z e)$ and male $\left({ }^{z e}\right)$. Larvae were raised on mulberry leaves at $25^{\circ} \mathrm{C}$.

\section{Induction of trimolter larvae by KK-42}

KK-42 dissolved in acetone was applied topically to the dorsal integument of t011 larvae shortly after the third molt ( $50 \mu \mathrm{l}$ per larva). The induction rates of trimolting larvae were 0,0 and $15.4 \%$ at the doses of $0,0.1$ and $0.5 \mu \mathrm{g}$, respectively, whereas $100 \%$ at the doses larger than $5.0 \mu \mathrm{g}$. Since no reduction in rate was seen by $50 \mu \mathrm{g}$ of the compound, this application dose was used in the following experiments. Control larvae received the vehicle alone.

\section{Sampling of haemolymph}

Haemolymph specimens of KK-42-treated larvae and control larvae were collected at $24 \mathrm{~h}$ intervals from day 0 (shortly after ecdysis) of the fourth instar to the onset of spinning and centrifuged to remove haemocytes as detailed previously (Kawaguchi et al., 1993). The supernatants were used for protein analyses as described below.

\section{Quantitative and qualitative analyses of haemolymph proteins}

The supernatants were made $1 \%$ with respect to trichroloacetic acid (TCA) and the precipitates were washed three times with $5 \%$ ice-cold TCA and with ethanol : ether (1: 1) to remove free amino acids and lipids and then dissolved in $0.1 \mathrm{~N} \mathrm{NaOH}$. The solution was analyzed for the concentration of proteins by Folin method using filter paper tips with bovine serum albumin as a standard (Hayashi, 1983).

Alternatively, the supernatants were subjected to polyacrylamide gel electrophoresis (Davis, 1964; Ornstein, 1964) using 6.5\% slabs (Kawaguchi et al., 1993). The proteins were stained with $0.1 \%$ Coomassie Brilliant Blue R-250 in ethanol : acetic acid : distilled water $(4: 1: 5)$ for $1 \mathrm{~h}$ and destained in $7 \%$ acetic acid.

\section{RESULTS}

\section{Changes in concentration of haemolymph proteins}

The protein concentration of haemolymph in the normal (control) larvae was low during the feeding period of the fourth instar, with little difference between sexes. At the 


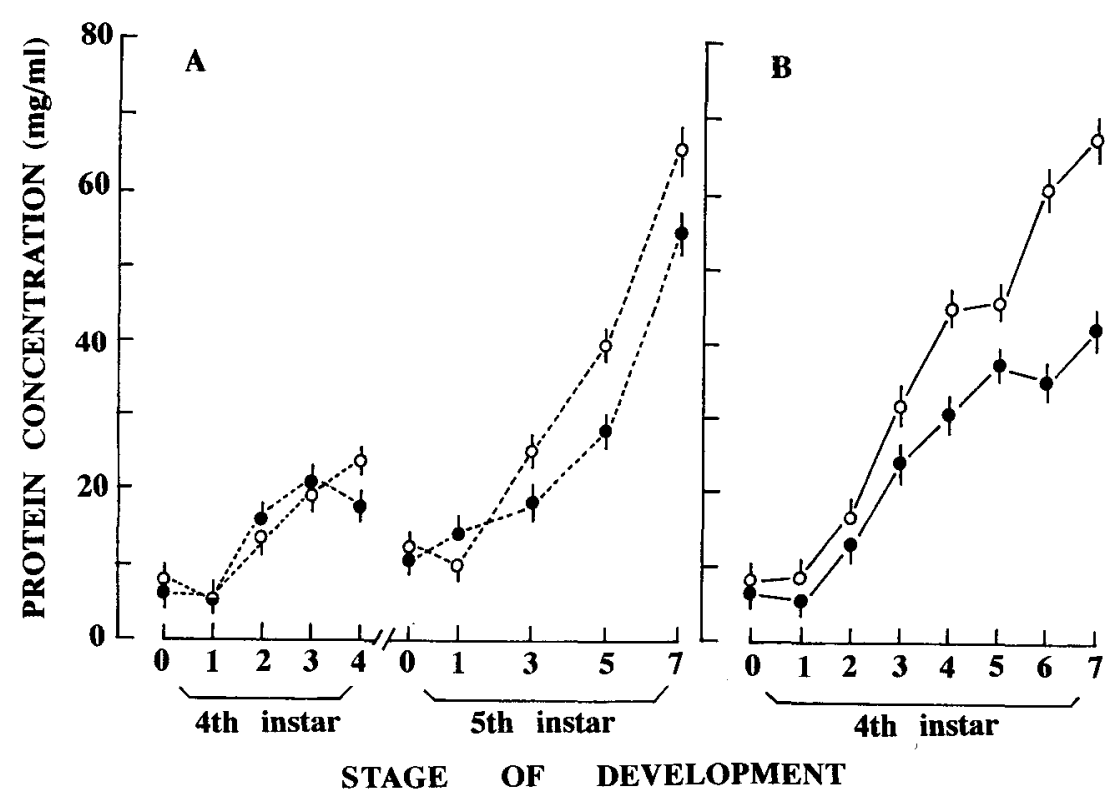

Fig. 1. Protein concentration of haemolymph in normal tetramolter and artificial trimolter induced by KK - 42 at the fourth and the fifth instars. A, normal tetramolter; B, induced trimolter. Open circles, females; closed circles, males. Day 0 means the period shortly after ecdysis. Each point represents the average of five measurements. Vertical bars, standard deviation.

fifth instar (the final instar for the control larvae), the concentration in both sexes rapidly increased. There was a marked sexual difference, the female predominating the male (Fig. 1A).

The trimolter larvae induced by KK-42 had prolonged fourth instar ( 7 days instead of the normal 4 days), and this was the final larval stage; the larvae began to spin on day 8 and then became precocious pupae. There was a rapid increase of protein concentration at the fourth instar with a marked sex-dependent difference (Fig. 1B) like the fifth instar of the control.

\section{Changes in component of haemolymph proteins}

The electrophoretic analysis of haemolymph proteins in the tetramolter (normal) larvae revealed major components as well as minor ones numbered 1 to 7 (Fig. 2A). All bands were weak during the fourth instar and until day 1 of the fifth instar. However, the bands became intense from days 3 to 7 of the fifth instar. The FL (SP-1) band was seen strongly in females at the late period of the fifth instar, but in males this band gradually became weak. On the other hand, the SP-2 band was observed in both sexes and rapidly increased in intensity. The behavior of FL makes the electrophoretic patterns markedly different between the sexes. 


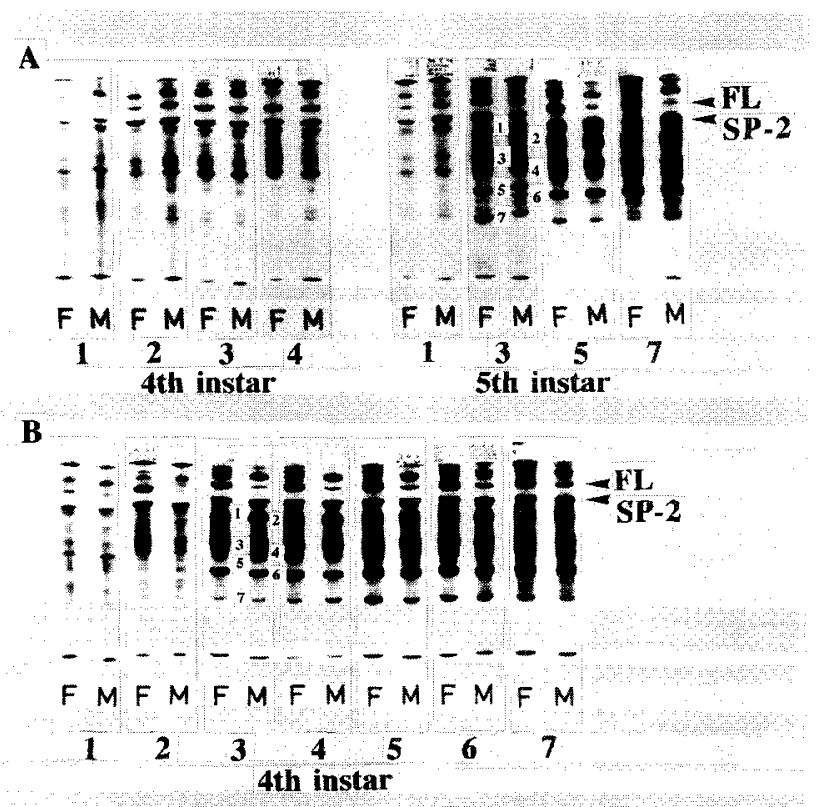

Fig. 2. Electrophoretic patterns of haemolymph proteins in normal tetramolter at the fourth and the fifth instars (A) and in induced trimolter at the fourth instar (B). F, females; M, males. FL, female specific protein (SP-1); SP-2, storage protein 2; Nos. 1-7, other components.

The patterns of haemolymph proteins at the fourth (final) instar of the induced trimolter larvae exhibited again major and minor components (Fig. 2B). On day 1, the bands were weak and no difference was observed between sexes. After day 3, most bands became strong; the FL band augmented in intensity only in females (in males this band seemingly fluctuated until the end of the fourth instar). As a whole, the protein profile at the late period (days 4 to 7 ) of the fourth instar in the induced trimolter larvae resembled that of the fifth instar in the normal tetramolter.

\section{DISCUSSION}

On the basis of quantitative and qualitative analyses of hemolymph proteins, the larval stages of $B$. mori could be divided into the following three phases (Kawaguchi et al., 1993). 1) The young larval phase at the first to the third instars, when the concentration of the haemolymph proteins is low and no difference in the banding-pattern is seen between both sexes. The presence of PYL-A and PYL-B components (see INTRODUCTION) is characteristic. These are the typical phase of nutritional growth. 2) The intermediary phase; the fourth larval instar in the case of the normal tetramolter. This is the stage during which the nutritional growth phase sifts to the following reproductive growth phase. The protein concentration is still low and there is no sexual difference. 3) The late larval phase at the last larval instar (the fifth instar in the case of 
Table 1. Summarized features of larval haemolymph proteins after quantitative and qualitative analysis in the artificial trimolters induced by KK-42 in comparison with other types of moltinism variants.

\begin{tabular}{|c|c|c|c|c|c|c|c|c|}
\hline \multirow{4}{*}{$\begin{array}{l}\begin{array}{l}\text { Animal } \\
\text { analyzed }\end{array} \\
\begin{array}{l}\text { Tetramolter } \\
\text { (control) }\end{array}\end{array}$} & \multirow{4}{*}{$\frac{\text { Genotype }}{+^{M}}$} & \multirow{2}{*}{\multicolumn{6}{|c|}{$\begin{array}{l}\text { Roman numerals : instar No. of larval life } \\
\text { Arabic numerals : instars specified by the } \\
\text { features of haemolympy proteins }\end{array}$}} & \multirow{4}{*}{$\begin{array}{l}\text { Characteristic } \\
\text { phenotypes of } \\
\text { haemolymph } \\
\text { proteins } \\
\text { Normal type* }\end{array}$} \\
\hline & & & & & & & & \\
\hline & & \multirow{2}{*}{$\frac{I}{(1)}$} & \multirow{2}{*}{$\frac{\text { II }}{2}$} & \multirow{2}{*}{$\frac{\text { III }}{3}$} & \multirow{2}{*}{$\frac{\text { IV }}{4}$} & \multirow{2}{*}{\multicolumn{2}{|c|}{$\frac{V}{5}$}} & \\
\hline & & & & & & & & \\
\hline \multirow{2}{*}{$\begin{array}{l}\text { Artificial trimolter } \\
\text { (induced by KK-42) }\end{array}$} & \multirow[t]{2}{*}{$+{ }^{M}$} & I & II & III & IV & & & Conjugation type \\
\hline & & $\overline{(1)}$ & $\overline{(2)}$ & $\overline{(3)}$ & $\overline{4+5}$ & & & $\begin{array}{l}\text { with the fourth and } \\
\text { the fifth instars } \\
\text { (incomplete) }\end{array}$ \\
\hline \multirow{2}{*}{$\begin{array}{l}\text { Artificial trimolter } \\
\text { (allatectomized-A) }\end{array}$} & \multirow[t]{2}{*}{$+M$} & $\mathbf{I}$ & II & III & IV & & & Conjugation type \\
\hline & & (1) & (2) & (3) & $4+5$ & & & $\begin{array}{l}\text { with the fourth and } \\
\text { the fifth instars } \\
\text { (complete)*** }\end{array}$ \\
\hline \multirow{2}{*}{$\begin{array}{l}\text { Artificial trimolter } \\
\text { (allatectomized-B) }\end{array}$} & \multirow[t]{2}{*}{$+{ }^{M}$} & I & II & III & IV & & & \multirow{2}{*}{$\begin{array}{l}\text { Conjugation type } \\
\text { with the fourth and } \\
\text { the fifth instars } \\
\text { (incomplete)*** }\end{array}$} \\
\hline & & $\overline{(1)}$ & (2) & (3) & $4+5$ & & & \\
\hline \multirow{2}{*}{$\begin{array}{l}\text { Genetic trimolter } \\
\text { (dominant) }\end{array}$} & \multirow[t]{2}{*}{$M^{3}$} & $\mathbf{I}$ & II & III & IV & & & \multirow{2}{*}{$\begin{array}{l}\text { Omission type } \\
\text { of the fourth } \\
\text { instar*** }\end{array}$} \\
\hline & & (1) & 2 & 3 & 5 & & & \\
\hline \multirow{2}{*}{$\begin{array}{l}\text { Genetic trimolter } \\
\text { (recessive) }\end{array}$} & \multirow[t]{2}{*}{$r t$} & $\mathbf{I}$ & II & III & IV & & & \multirow{2}{*}{$\begin{array}{l}\text { Conjugation type } \\
\text { with the fourth and } \\
\text { the fifth instars } \\
\text { (complete)*** }\end{array}$} \\
\hline & & (1) & 2 & $\mathbf{3}$ & $4+5$ & & & \\
\hline \multirow{2}{*}{$\begin{array}{l}\text { Genetic pentamolter } \\
\text { (recessive) }\end{array}$} & \multirow[t]{2}{*}{$M^{5}$} & $\mathbf{I}$ & II & III & IV & $\mathbf{V}$ & $\underline{\text { VI }}$ & \multirow{2}{*}{$\begin{array}{l}\text { Duplication type } \\
\text { with the fourth and } \\
\text { the fourth instar*** }\end{array}$} \\
\hline & & (1) & 2 & 3 & 4 & 4 & 5 & \\
\hline
\end{tabular}

* Cf. also Kawaguchi et al. (1993). ** Cited from Kawaguchi et. al. (1994). *** Cited from Kawaguchi et. al. (1993). Parentheses indicate the characteristics apparent without analysis.

normal tetramolter), when the haemolymph protein concentration rapidly increases and the significant differences in concentration and composition of haemolymph proteins are recognized between both sexes. This largely depends on the female-specific increase of $\mathrm{FL}$, which may serve as an indispensable resource of yolk formation. Thus the last larval instar is taken to be a phase in which the reproductive growth is already taking place.

In the light of the above criterion, the final instar of the trimolter larvae induced by KK-42 could be characterized in Table 1 . We conclude that the present trimolter had an intermediary phase on day 1 of the last (fourth) instar (one day after the treatment of KK-42) when the banding intensity of haemolymph proteins was weak without sexual difference. Namely, this trimolter seemed to possess the conjugated fourth plus fifth instars as the final larval stage.

These characteristics were similar to those of trimolters-A and B induced by allatectomy before and after, respectively, the third molt to mimic molting mutants (Table 1, cf. Kawaguchi et al., 1994; the present trimolter induced by KK-42 may have a 
similarity to trimolter-B, the incomplete conjugation type with intermediary amounts of $\mathrm{FL}$, although details remain to be elucidated). As reported previously, these trimolters resembled the recessive trimolter mutant $r t$ rather than the dominant trimolter $M^{*}$, which exhibited no fourth-instar type intermediary growth phase (Table 1, cf. Kawaguchi et al., 1993). $M^{5}$ has duplicated fourth-instar type intermediary growth phases and completely different from $M^{3}$ (KK-42 treatment or allatectomy to the $M^{5}$ mutant will be promising).

Also the present finding supported our previous notion (Kawaguchi et al., 1993) that the modification of the molting number occurs via the skipping, shortening or duplication of the intermediary phase; all types of moltinism variation shown above scarcely affected the reproductive as well as nutritional growth phase of larval life.

The mode of action of KK-42 in the induction of precocious maturation is shown to be mainly related to its inhibitory effect upon the ecdysteroid synthesis (Kadono-Okuda et $a l ., 1987)$. However, the present trimolter was induced by KK- 42 treatment shortly after the third molt when the corpora allata are still active and the anti-juvenile hormone activity of KK-42 (Suzuki and Kuwano, 1994) may be effective. Further analyses of haemolymph proteins after treatment with this insect growth regulator at different developmental stages following the third molt will be of interest.

\section{ACKNOWLEDGMENTS}

This study was supported in part by a Grand-in-Aid for Scientific Research (Nos. 07406004 and 08406006) from the Ministry of Education, Science and Culture of Japan.

\section{REFERENCES}

Asano S., E. Kuwano and M. Eto 1984 Anti-juvenile hormone activity of 1-citronellyl-5-phenylimidazole in the 3rd instar silkworm, Bombyx mori L. Appl. Ent. Zool. 19:212-220.

Banno Y., S. Tochihara., Y. Kawaguchi and H. Doira 1993 Hemolymph proteins during larval development of Bombyx mori: "Proteins of young Larvae". J. Seric. Sci. Jpn. 62: 187-194.

Davis B. J. 1964 Disc electrophoresis II. Method and application to human serum protein. Ann. N.Y. Acad. Sci. 121: Pt. 2, 404-427.

Doira H. 1968 Developmental and sexual differences of blood protein in the silkworm, Bombyx mori. Sci. Bull. Fac. Agric. Kyushu Univ. 23: 205-514.

Doira H., H. Fujii, Y. Kawaguchi, H. Kihara and Y. Banno 1992 Genetical Stocks and Mutations of Bombyx mori: Important Genetic Resources - 1992-. Institute of Genetic Resources, Faculty of Agriculture, Kyushu University, Fukuoka, 73 pp.

Fujiwara Y. and $O$. Yamashita 1990 Purification, characterization and developmental changes in the titer of a new larval serum protein of the silkworm, Bombyx mori. Insect Biochem. 20: 751-759.

Fukuda S. 1940 Hormonal control of corpus allatum in the silkworm. J. Seric. Sci.Jpn. 16: 417-420.

Hayashi H. 1983 A filter paper technique for the microdetermination of protein. Seikagaku 55: 257-258.

Kadono-Okuda K., E. Kuwano, M. Eto and O. Yamashita 1987 Inhibitory action of an imidazole compound on ecdysone synthesis in prothoracic glands of the silkworm, Bombyx mori. Develop. Growth and Differ. 29: 527-533.

Kawaguchi Y. and H. Doira 1973 Gene-controlled incorporation of haemolymph protein into the ovaries of Bombyx mori. J. Insect Physiol. 19: 2083-2096.

Kawaguchi Y., H. Fujii and H. Doira H 1983 Changes in haemolymph protein during larval development of the dimolting mutant in Bombyx mori. J. Seric. Sci. Jpn. 56: 517-523.

Kawaguchi Y., Y. Banno, K. Koga, H. Doira and H. Fujii 1993 Characteristic profiles of haemolymph proteins during larval development of molting mutants of the silkworm, Bombyx mori. Comp. 
Biochem. Physiol. 105B: 361-367.

Kawaguchi Y., Y. Banno, K. Koga, H. Doira and H. Fujii 1994 Haemolymph protein profiles in allatectomyinduced trimolters resemble those of a recessive trimolting mutant of the silkworm, Bombyx mori. Comp. Biochem. Physiol. 107B: 579-584.

Kim S. B. 1936 On the hormone of corpus allatum in the silkworm, Bombyx mori. J. Seric. Sci. Jpn. 10: 86-97.

Kobara R. 1967 Sexual difference in haemolymph protein of several insects. Jpn. J. Appl. Ent. Zool. 11: $71-75$

Kuwano E. 1984 Recent topics in studies on anti juvenile hormone agents. Syokubutsu Boueki. 41:392397.

Kuwano E., T. Hisano, M. Eto, K. Suzuki, G. C. Unnithan and S. Bowers. 1992 Insect growth regulating activity of 1,5-disubstituted imidazoles against Bombyx mori and Oncopeltus fasciatus. Pestic. Sci. 24: $263-268$.

Ornstein L. 1964 Disc electrophoresis I. Background and theory. Ann. N. Y. Acad. Sci. 121: Pt. 2, 321-349.

Suzuki K. and E. Kuwano 1994 Control of insect diapause by imdazole derivatives. Kagaku-to-Seibutsu. 32: $221-228$.

Tojo S., M. Nagata and M. Kobayashi 1980 Storage proteins in the silkworm, Bombyx mori. Insect Biochem. 10: 47-53. 